\title{
Effect of Transformational Leadership and Characteristics of Working Group on Educator Work Satisfaction (Study at Huria Kristen Batak Protestan (HKBP) Private High School in North Sumatera)
}

\author{
A.Simaremare ${ }^{1}$, Yusnadi ${ }^{2}$, S.Handayani ${ }^{3 *}$, Nurmaniah $^{4}$ \\ \{tuansimare@unimed.ac.id ${ }^{3}$ \} \\ Universitas Negeri Medan, Medan, North Sumatera, Indonesia ${ }^{1,2,3,4}$
}

\begin{abstract}
This study aims to determine the effect of transformational leadership and work group characteristics on the job satisfaction of educators in HKBP Private High Schools in North Sumatra Province. The population of this study was all full-time educators at HKBP Private High School with a sample of 131 taken by proportional random sampling technique. The research data was collected through questionnaires and analyzed with path analysis techniques. The results of the study showed that transformational leadership and the characteristics of the working group had a significant effect on the job satisfaction of educators. Conclusion, the more effective the transformational leadership of the principal is the higher job satisfaction, and the higher the support characteristics of the working group the higher the job satisfaction of the educator. The implication of the results of this study explains that to improve educator job satisfaction can be done by increasing the effectiveness of the principal's transformational leadership and the development of the characteristics of educator working groups..
\end{abstract}

Keywords: Transformational leadership, characteristics of working groups, job satisfaction.

\section{Introduction}

Educators as human resources in schools have a central position in order to achieve the vision, mission, and goals of the school. Educators are the key factor in the implementation of education in schools. Educators are the leading executors who cannot be replaced by technology even in the teaching and learning process in the classroom. Educators as human resources are most important inputs needed for the ongoing process of education in schools [1]. Educators play a strategic role, especially in the effort to shape the character of the nation through the development of desirable personalities and values [2]. The sophistication or technological advances that exist in schools cannot be used to shape the character of the nation but must still be in the hands of humans, namely educators.

A symptom that can make damage to the condition of the private school organization is the low job satisfaction of educators which results in dissatisfaction phenomena such as the desire to change jobs, absenteeism, being late, opposing leadership policies, refusing suggestions, high turnover, complaining, low quality of teaching, want to stop working, or working at another school. The existence of educators in schools must be seen as the highest capital of school organizations that have the potential, competence, attitudes and behavior that can be transformed into positive attitude towards their work so that they can gladly make a large contribution to school development and progress in the future. Those dissatisfactions seem to occur in schools run by the HKBP foundation which both quantity and quality dropped drastically. In the 1970s the number of schools managed by HKBP was 150 units [2] while in 2012 only 83 units from kindergarten to tertiary level [3], especially high schools also experienced a decline in the number of 17 units in 2012 to 14 units in 2013 [4].

Principals as leaders in school management need to pay attention to the psychological condition of educators so that they remain motivated and eager to succeed in achieving school organization goals. Growing and maintaining educator satisfaction towards their work is an important task that must be considered and realized by the school management so that it can have a positive impact on their work behavior in school. An educator who is satisfied with his job will tend to like and give the best and will even strive to meet the needs 
of the subjects/objects he loves and is willing to sacrifice [4], the quality of the organization (school) is increasing, educators do not want to get out of their jobs, attendance is high, carrying out tasks on time, high morale, showing friendly attitude in serving, mentally and physically healthy, complete the task quickly, and do not like to complain [5], creating an educational atmosphere that is meaningful, fun, creative, dynamic, and dialogical, has a professional commitment to improve the quality of education, and exemplifies the good name of the institution, profession, and position in accordance with the trust given to him [6-7]. Teachers who are satisfied with their work will be productive, will develop and maintain a high level of performance, making the teaching and learning process more efficient and effective so as to produce students who highly competitive [8].

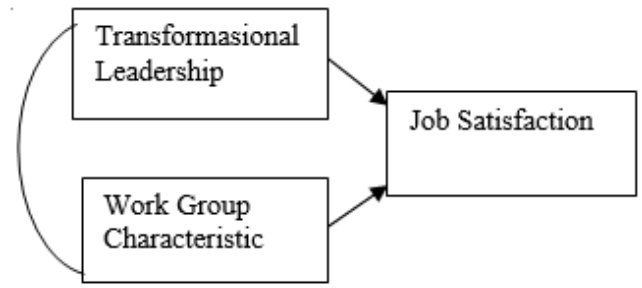

Fig. 1. Research Theoritical Model

Job satisfaction as a psychological force that encourage individuals to have motivation and enthusiasm in achieving organizational goals is influenced by various factors, including compensation, promotion opportunities, job security, working conditions and the work itself [8-9], remuneration and awards received [9], reward and recognition, supervision [4], organizational climate [10], transformational leadership, individual performance, financial compensation system [11], transformational leadership [12], interpersonal communication [13] and achievement of goals [14].

According to House, job satisfaction was influenced by perceptions and individual motivation, leadership style (directive, supportive, participative, and achievement-oriented), individual characteristics (locus of control and ability), and organizational environment, task characteristics, formal autority systems, and primary work groups [15]. Lawler and Porter explained that job satisfaction is determined by individual perceptions of rewards obtained based on performance [16-17]. Fratrat and Starke also state that job satisfaction is determined by various factors that support one another: employee need structure, job motivation, productivity, rewards [18]. Robbins \& Judge (2008) also explain the possibilities that make a person feel satisfied in their work is the job itself, wages or salaries, promotions, and co-workers. Korman (1978) states that the factors that can determine the formation of job satisfaction are occupational levels, job content, attentive leadership, payment and promotion opportunities, and social interaction in work groups.

Based on the explanation above it can be stated that job satisfaction is influenced by a number of variables, but in this study is limited to the leadership qualifications of principals and the characteristics of educator working groups. The principal's leadership is an important element in realizing the achievement of goals and advancing school and maintaining its existence. Success of managing a school to achieve its goal is a manifestation of the ability of the principal as a leader to mobilize and utilize the resources in the school [20]. One form of leadership carried out by the principal realizing the achievement of school goals is transformational leadership. Transformational leadership carried out by principals is motivating followers to increase their level of understanding of usability and value from detailed and ideal goals, making them express the interests of the team or organization rather than personal interests, and move them to try to meet the needs of higher levels [21].

The essence of transformational leadership is to empower followers to perform effectively by building their commitment to new values, developing their skills and beliefs, creating a climate conducive to the development of innovation and creativity [22], so followers feel high psychological satisfaction in his work. The success of an organization achieving its goals is also inseparable from the influence of the working group's characteristics. The working group is a number of individuals involved in a particular field of work where there is a reciprocal relationship between individuals who are bound psychologically, resulting in mutual dependence on one another and having the same interests to achieve organizational goals. The effectiveness of collaboration in work groups has an impact on group outcomes, one of which is job satisfaction [23]. Thus, it is assumed that transformational leadership and work group characteristics can influence the job satisfaction of educators. 


\section{Methodology}

This type of research is classified as expose facto causal research. The target population of this study were all permanent teachers who served at HKBP Private Senior High School in North Sumatra with N $=292$ teachers while the sample unit size was determined by referring to Harry King's Nomogram Table of $45 \%$ with 0.05 precision $=131$ teachers, and the selection of samples using proportional random sampling. Data collection was conducted through questionnaires that had been tested for validity and reliability, while the research data were analyzed using descriptive and inferential statistical analysis. Hypothesis testing is done by path analysis.

\section{Results and Discussion}

Descriptive data analysis results are presented in Table 1 below:

Table 1. Summary of Results of Descriptive Data Analysis of Research Variables

\begin{tabular}{|c|c|c|c|c|}
\hline \multirow{2}{*}{ No } & \multirow{2}{*}{ Statistic Descriptive } & \multicolumn{3}{|c|}{ Results } \\
\hline & & $\mathbf{X}_{1}$ & $\mathbf{X}_{2}$ & $\mathbf{X}_{3}$ \\
\hline 1 & Sample (N) & 131 & 131 & 131 \\
\hline 2 & Minimum Skor & 63 & 61 & 62 \\
\hline 3 & Maximum Skor & 185 & 164 & 149 \\
\hline 4 & Range & 122 & 103 & 62 \\
\hline 5 & Number of Interval Class & 8 & 8 & 8 \\
\hline 6 & Length of Interval Class & 16 & 13 & 11 \\
\hline 7 & Mean $(\mathrm{M})$ & 132,76 & 118,21 & 112,25 \\
\hline 8 & Median (Me) & 139,37 & 124,25 & 114.12 \\
\hline 9 & Modus (Mo) & 161,70 & 136,14 & 119,80 \\
\hline 10 & Deviation Standard & 34,50 & 28,31 & 19,69 \\
\hline 11 & Ideal Minimum Skor & 41 & 36 & 33 \\
\hline 12 & Ideal Maximum Skor & 205 & 180 & 165 \\
\hline 13 & Ideal Mean & 123,50 & 108 & 99 \\
\hline \multirow[t]{2}{*}{14} & Ideal Deviation Standard & 27,33 & 24 & 22 \\
\hline & Total & 17392 & 15485 & 14705 \\
\hline
\end{tabular}

X1: Transformational Leadership;

X2: Characteristics of Working Groups

X3: Job Satisfaction

Based on the data analysis above it can be seen that:

(a) In general, educator job satisfaction is in the medium category with an average of 112.25. Analysis results of the overall aspects of job satisfaction are the highest aspect of satisfaction perceived by educators is found in the aspect of the job itself with an average value of 4.33 while the lowest perceived satisfaction is on the payroll aspect with an average value of 2.59 .

(b) Principal transformational leadership is categorized as sufficient with an average of 118.21. Analysis results on the principal's transformational leadership dimensions indicate that individualized consideration is the highest average value of 3.70, and the lowest is intellectual stimulating of 2.82 .

(c) Support characteristics of the educators working group are quite sufficient with an average value of 132.76. Analysis results of the characteristics of the working group showed the group cohesiveness indicator gave the highest support with an average value of 3.88 and the lowest was the composition of the group with an average value of 2.71 .

After analyzing the correlation between variables, then continued with path analysis of the research variables. The summary of the path coefficient estimation results on the research variables is presented in Table 2. 
Table 2. Summary of Calculation Results of Pathway Coefficients

\begin{tabular}{llllll}
\hline & Coefficient & $\mathbf{t}_{\mathbf{h}}$ & $\mathbf{t}_{\mathbf{t}(\mathbf{0}, \mathbf{0 5})}$ & $\mathbf{t}_{\mathbf{t}(\mathbf{0}, \mathbf{0 1})}$ & \\
\hline$\rho_{31}$ & 0,19 & 2,51 & 1,65 & 2,33 & Very Significant \\
$\rho_{32}$ & 0,19 & 2,59 & 1,65 & 2,33 & Very Significant \\
\hline
\end{tabular}

Based on the data analysis above, it can be stated that transformational leadership has a direct and positive effect on the job satisfaction of educators in HKBP private high schools north sumatera. And it also can be stated that the characteristics of work group directly and positively influence the job satisfaction of educators in HKBP private high schools north sumatera. Based on the path coefficients obtained, we can illustrate the model path diagram in figure 2 below.

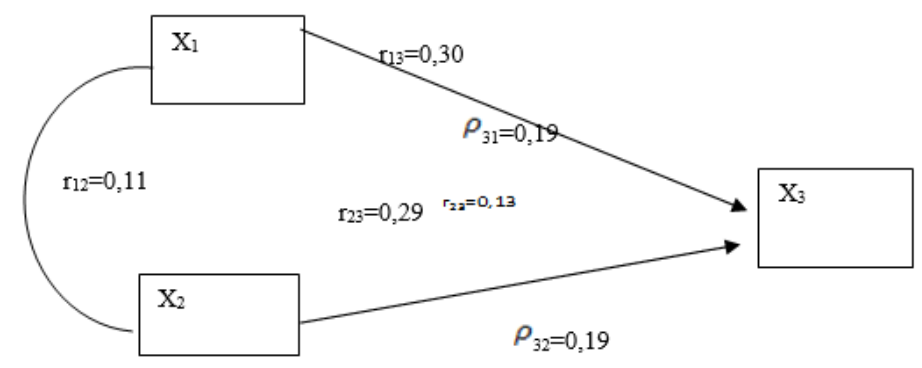

Fig. 2. Empirical Causal Relationships $X 1, X 2, X 3$, and $X 4$ to $X 5$

Based on the calculation results, it can be explained that various matters concerning the influence of each exogenous variable includes transformational leadership and work group characteristics to variable job satisfaction as endogenous variables. The calculation results of influence are presented in Table 3 below.

Table 3. Summary of Direct and Indirect Influences on X3

\begin{tabular}{lll}
\hline Variable & $R$ & Direct \\
\hline $\mathrm{X}_{1}$ & 0,30 & 0,19 \\
$\mathrm{X}_{2}$ & 0,30 & 0,19 \\
\hline
\end{tabular}

The first hypothesis, shows the high and low job satisfaction of educators directly influenced by transformational leadership (x1) of 0.19 . The second hypothesis, shows the high and low satisfaction of educators influenced by the characteristics of the work group (x2) of 0.19 .

The results of testing hypotheses have shown that educator job satisfaction is influenced by transformational leadership and the characteristics of work groups. The more effective principal's transformational leadership, the higher the job satisfaction of educators, and the better the support of the characteristics of the work group, the higher the job satisfaction of educators. This finding explains that educator job satisfaction can be improved through the effectiveness of principal's transformational leadership and the development of work group characteristics. Therefore, the effectiveness of the principal's transformational leadership still has to be improved in order to increasing job satisfaction of educators. Psychologically, from each educator as an inseparable group member, there is a feeling of mutual assistance, mutual support, and a sense of mutual interest in achieving the goals of the school organization. Working groups based on strong psychological ties are believed to be one of the motivations of educators to remain loyal to their work groups and can increase high job satisfaction.

Three variables examined in this study are all in the sufficient category. This shows that educators have not felt the maximum support from the school organizers or foundations as one of the main responsible elements in the empowerment of human resources and the support of educators in schools. This is in accordance with one of the basic principles of HKBP education management item 2.10. which states that the empowerment of educational institution human resources is the key to achieving success in the effort to 
improve the quality of sustainable human resources, including teachers / lecturers, leaders, academic support staff and administrative staff. This HR empowerment system consists of pre-service training, education/training in positions, and welfare (salary, etc.).

In terms of management theory, descriptive research findings can be said that the education management system practiced practically in HKBP education still has not paid attention to the psychological and sociological variables of educators optimally, but educators are required to achieve good school education results. This is in accordance with scientific management theory initiated by Fredrik W. Taylor to focus his attention on physical production or satisfactory results or performance, not paying attention to the psychological and sociological variables of employees. The orientation of Taylor's theory is that direct production increases that tend to equate workers with machines, need attention from their supervisors in order to work and provide high productivity [23]. This finding suggests that the management of HKBP education providers needs to apply a human relations orientation approach, as initiated by the Hawthorne Study with its followers such as Elton Mayo, Fritz J. Roethlisberger, Abraham Maslow, and others. This theory views that human relations in management are in the organizational context. This means that the informal working group of employees' social environment has a big influence on productivity, there needs to be attention to social needs and self-actualization of employees so that he is eager to work as an opportunity to excel himself without any supervision. This human relations approach suggests that managers use psychological techniques that are associated with human behavior, greater attention to employees. Thus to improve the condition of educators, management of the HKBP education foundation needs to make the school organization a "happy big family" with an emphasis on educator motivation and satisfaction as well as group spirit that results in a commitment to achieving the goals of the school organization.

Job satisfaction can grow and develop in a person because it is supported by a number of factors. The results of previous studies have proven this. Research by Irma Taba and Ozaira Zafar concluded that compensation, promotion opportunities, job security, working conditions and the work itself could positively influence the level of job satisfaction of academic staff at state and private universities in Pakistan. Gathungu \& Wachira's (2013) study also found that remuneration and rewards have an influence on job satisfaction if only considered fair. Shah et al. (2012) found that there was a significant and positive relationship between reward and recognition, supervision, and work itself, with job satisfaction. The results of these studies have supported the theories put forward by experts that there are a number of determinants of job satisfaction. This can be seen from the Robert House Path-Goal Theory, and the theory of job satisfaction from other experts such as PorterLawler, Ferratt and Starke; [24-25] and Howel and [26]. The findings of this study have supported these theories by demonstrating that transformational leadership factors and the characteristics of work groups can influence the job satisfaction of educators. It means that:

(a) Principal's transformational leadership needs to be improved in order to increase the work satisfaction of educators. The findings of this study support the opinion of DA Waldiman\& FJ Yammirino and B Shamir. RJ House \& MB Arthur stated that the results obtained as an effect of the behavior of transformational leaders shows the personal commitment of followers to their leaders and visions, arising self-sacrifice behavior of followers for the sake of the organization, organizational commitment, satisfaction with followers because they feel duty what he does is meaningful for himself and for the organization. This finding also supports the results of MarnisAtmojo's research which states that: transformational leadership significantly influences job satisfaction. Ni Komang Sukertiasih's research also shows that authentic transformational leadership has both direct and indirect effects on teacher job satisfaction. According to this theory the effect of leader behavior results in an increase in intrinsic motivation, achievement, and willingness of the followers and work groups voluntarily to achieve goals have an impact on increasing job satisfaction perceived by employees in carrying out their duties.

(b) Characteristics of work groups can determine the high and low level of educators' job satisfaction. The findings of this study suggest that educators will feel a high level of job satisfaction if supported by the characteristics of a good working group such as the support of a group composition state, the recognition of one's status in the group (hierarchy of status), a person can carry out his role in accordance with his position or status group, each group member acts according to group norms, group leaders can carry out their roles in a balanced manner between task demands and maintaining human relations, and are supported by high group cohesiveness so that members have a strong commitment to support the achievement of group goals and objectives. This is consistent with the 
group formation model theory and its development proposed by [27], which states that the results of the characteristics of the working group have an impact on the performance, satisfaction, and development of the next group. [22] stated that the higher the level of group cohesiveness, the higher the performance and satisfaction of group members. This finding supports the theory put forward by Coulquitt, LePene, and Wasson in an integrative model of organizational behavior that places job satisfaction as one of the variables of individual mechanisms directly influenced by the group mechanism, namely leadership, processes and characteristics of the team or work group. This finding also supports the statements of Ivancevich, Konopaske and Matteson in the group formation and development model, that job satisfaction is directly affected by the characteristics of work groups. In connection with this, there needs to be a good working interaction between one educator and another educator even with education personnel in other school, helping each other, encouraging each other, and supporting each other for the realization of high attitudes of educator job satisfaction in schools.

\section{Conclusion}

Based on the results of data analysis and discussion of research results, a number of information can be summarized as follows:

a. The tendency of transformational leadership, characteristics of work groups, and job satisfaction of educators is in the sufficient category.

b. Transformational leadership directly affects the work satisfaction of educators. That is, the more effective the transformational leadership of the principal, the higher the level of job satisfaction of educators.

c. Characteristics of work groups directly influence the job satisfaction of educators. That is, the better the support of the characteristics of the working group, the higher the level of job satisfaction of educators.

\section{References}

[1] S. Rivai, Veithzal \& Murni, Educational Management; Analisis Teori dan Praktik. Jakarta: Rajawali Pers, 2009.

[2] J. S. Aritonang, Sejarah Pendidikan Kristen di Tanah Batak. Jakarta: BPK Gunung Mulia, 1988.

[3] HKBP, Laporan Penelitian HKBP, 2012. Pearaja-Tarutung: Kantor Pusat HKBP, 2012.

[4] Prayitno, "Pendidikan: Dasar Teori dan Praksis," in Jilid 1, Padang: UNP Press, 2009.

[5] J. W. Davis, Keith \& Newstrom, "Perilaku Organisasi," in Jilid 1. Alih Bahasa Agus Dharma, 7th ed., Jakarta: Gelora Aksara Pratama, 1990.

[6] "Undang-Undang Republik Indonesia Nomor 20 Tahun 2003 tentang Sistem Pendidikan Nasional."

[7] O. Saba, Iram \& Zafar, "Determining the Job Satisfaction Level of the Academic Staff at Tertiary Academic Institutes of Pakistan,” Int. SAMANM J. Mark. Manag., vol. 1, no. 2, pp. 1-11, 2012.

[8] H. W. Gathungu, James \& Wachira, "Job Satisfaction Factors that Influence the Performance of Secondary School Principals in their Administrative Functions in Mombasa District, Kenya," Int. J. Educ. Res., vol. 1, no. 2, pp. 1-15, 2013.

[9] A. Shah, Muhammad Jamal., Rehman, Musawwir-Ur., Akhtar, Gulnaz., Zafar, Huma., \& Riaz, "Job Satisfaction and Motivation of Teachers of Public Educational Institutions," Int. J. Bus. Soc. Sci., vol. 3, no. 8, pp. 271-280, 2012.

[10] Rismayani \& Hartini, "Pengaruh Iklim Organisasi terhadap Kepuasan Kerja Biro Pusat Administrasi Universitas Sumatera Utara Medan,” J. Komun. Penelit. Vol., vol. 18, no. 1, pp. 28-37, 2006.

[11] N. K. Sukertiasih, "Pengaruh Kepemimpinan Transformasional yang Otentik terhadap Kepuasan Kerja Guru SMA Saraswati Mataram,” Gane Swara, vol. 3, no. 3, pp. 59-66, 2009.

[12] Restu, "Pengaruh Budaya Organisasi, Kepemimpinan Transformasional, Kepribadian, Kepuasan Kerja dan Motivasi Berprestasi Terhadap Kinerja," Disertasi. PPs. Unimed, 2012.

[13] T. A. Siburian, "Pengaruh Komunikasi Interpersonal, Budaya Organisasi, Kepuasan Kerja, dan Motivasi Berprestasi terhadap Komitmen Organisasi Guru SMA Negeri di Kabupaten Humbang Hasundutan," Disertasi PPs. Unimed, 2013. 
[14] S. Milfayetty, "Pengaruh Kebutuhan Transendensi, Kesadaran Berorganisasi, Kejelasan Peran dalam Pencapaian Tujuan terhadap Kepuasan Kerja," Disertasi PPs UNJ, 2009.

[15] M. Robbins, Stephen P., \& Coulter, "Manajemen," in Jilid 2. Alih Bahasa: Harry Slamet \& Ernawati Lestari, 8th ed., Jakarta: PT. Indeks, 2007.

[16] W. . Dipboye, R.L., Smith C.S., \& Howell, "Understanding Industrial and Oragnizational Psychology," in An Integrated Approach, Tokyo: Harcourt Brace College Publishers, 1994.

[17] L. W. Hackman, J. Richard., Lawler III, Edward E., \& Porter, Perpectives on Behavior in Organizations. New York: McGraw-Hill Book Company, 1983.

[18] S. Oscamp, Applied Social Psychology. Englewood Cliffs. New Jersey: Prentice-Hall, Inc, 1984.

[19] T. A. Robbins, Stephen P., \& Judge, "Perilaku Organisasi," in Jilid 1. Terjemahan: Diana Angelica, Jakarta: Salemba Empat, 2008.

[20] A. . Korman, Organizational Behavior. New Delhi: Prentice Hall of India, 1978.

[21] P. G. Northouse, Kepemimpinan: Teoridan Praktik. Diterjemahkan Ati Cahayani, 6th ed. Jakarta: PT. Indeks, 2013.

[22] Y. Gary, Leadership in Organization. London: Prentice Hall International Inc, 1998.

[23] M. T. Ivancevich, John M., Konopaske, Robert., \& Matteson, Perilakudan Manajemen Organisasi. Alih Bahasa: Gina Gania. Jakarta: Erlangga, 2005.

[24] C. G. Hoy, Wayne K., \& Miskel, Educational Administration: Theory, Research and Practice. Toronto: Random House, Inc, 2001.

[25] M. J. Colquitt, Jason A., Lepine, Jeffery A. \& Wesson, Organizational Behavior. New York: McGraw-Hill Companies, Inc, 2009.

[26] M. Jewell, L.N., \& Siegal, Psikologi Industri/Organisasi Modern. Alihbahasa: A. Hadyana Pudjaatmaka \& Meitasari, 2nd ed. Jakarta: Arcan, 1998.

[27] "Kebijakan Dasar Pendidikan Huria Kristen Batak Protestan (KDP-HKBP)," 2000. 
